\title{
The Role of Education in Combating Violent Extremism in Developing Countries with an Emphasis on Afghanistan
}

Manuscript ID:

EDU-2021-09033830

Volume: 9

Issue: 3

Month: June

Year: 2021

P-ISSN: 2320-2653

E-ISSN: 2582-1334

Received: 12.03.2021

Accepted: 24.04.2021

Published: 01.06.2021

Citation:

Mohammadi, Mohammad.

"The Role of Education in Combating Violent Extremism in Developing Countries with an Emphasis on Afghanistan." Shanlax International Journal of Education, vol. 9, no. 3, 2021, pp. 273-287.

DOI:

https://doi.org/10.34293/ education.v9i3.3830

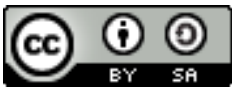

This work is licensed under a Creative Commons Attribution-ShareAlike 4.0 International License

\author{
Mohammad Mohammadi \\ Contract Lecturer, Herat University, Herat, Afghanistan \\ https://orcid.org/0000-0002-3056-4726
}

\begin{abstract}
Education as a pervasive process has affected all aspects of individual and group life, and today, almost all those seeking development and reform start from all over the world. Preventing radicalization and violent extremism is one of the most controversial issues in the world in this century. In addition, it was found that some extremist groups are recruiting in educational settings. These findings led to a new approach to the education sector as a prominent partner in preventing and combating the radicalization of young people. Education faces many challenges in developing countries, including Afghanistan. With the change of world views, cultures and different beliefs of human beings, the goals of education have also changed and according to this, there is a direct relationship and coordination between society and education. The inefficiency of the education system in different sections of the society will have adverse effects and dangerous consequences, as can be seen from the findings, lack of inclusive education, lack of quality in education and lack of job opportunities after graduation are recommended to strengthen the role of education for sustainable development in developing countries, especially Afghanistan because education is the cornerstone of development. One of the most important and influential institutions, investing in equal education and creating a safe environment for students at different levels (primary, secondary and tertiary) and adopting sensible strategies can be in the process. Integration, convergence, peaceful coexistence and the elimination of violence between peoples and nations have brought about many effects and changes.
\end{abstract}

Keywords: Education, Radicalization, Extremism, Prevention, Developing countries, Afghanistan

\section{Introduction}

In the present century, radicalization and extremism that lead to terrorism have taken root like a virus in most countries of the world, especially in developing countries, and have endangered large parts of our planet. \{is even though approximately 19 attacks were carried out daily by religious extremists around the world\}. Its effects are undoubtedly felt in all countries of the world. The crises in the Middle East, for example, have had a devastating effect on the lives of all humanity, as the world's oil as well as a significant volume of world trade, especially Europe, passes through the Middle East, especially the Suez Canal, the Strait of Bab al-Mandeb and the Strait of Hormuz. Successive wars of insecurity and violent extremism in Afghanistan led to the September 11 attacks and inflicted heavy casualties. This problem arose in Afghanistan but extended to the Americas. Since globalization affects and influences everything that happens in the world, no country can stay away from it, but everyone should think about finding a solution to these problems. As we know, extremism has caused different views among humanity and different religions; sects and sects are attacking each other to show themselves superior and right in any way and do not hesitate to do anything. It is a fact that the victims of terrorism originate 
more from developing countries because most terrorist attacks have taken place in them (for example, Afghanistan, Iraq, Nigeria, Syria, Pakistan and Somalia) and are spreading to other countries. Based on life expectancy, education and real income, 151 countries can be considered as developing countries.

For example, according to the translation group of "Hawzah" news agency" according to the Independent, a European poll conducted by Europe says that Europe saw the highest number of farright terrorist attacks in 2019. \{Overall, Europol announced that EU member states had reported 119 terrorist attacks and conspiracies in 2019. Of these, 57 were classified as ethnic-nationalist and separatist terrorism\}. This may hurt the results of sustainable development and world peace. On February 29, 2020, the United States and the Taliban signed a peace agreement in Doha, Qatar. Following the agreement with the United States, the talks with the Afghan government took place, and the Afghan government must release 5,000 Taliban prisoners by March 10, 2020, the start of inter-Afghan talks. With the start of the "inter-Afghan" negotiations and Afghanistan's approach to peace, ISIS has launched several attacks around Afghanistan to disrupt the peace process in Afghanistan. Of course, this group is likely to be supported by neighboring countries, especially Pakistan. These groups kill people in the name of religion and caliphate, and killing people by mentioning the name of God, burning, beheading, etc. is not the only thing that violent extremists do; they kill children and teenagers by Offering harsh religious lessons turn them into executioners who have never seen such figures in history! They steal their souls and identities and use them as weapons to gain power and to establish themselves and their extremist ideas. According to different definitions, there are ambiguities in the concept of radicalism, and in the definition of extremism, such ambiguities can be seen. There is inconsistency in the use and understanding of these terms and the lack of a proper and universal consensus on an extremist or a terrorist. An extremist may be a hero to some, and while not all extremists become terrorists, all terrorists are certainly extremists. Concepts of violent extremism are particularly problematic because they are politically and emotionally accused of humanity. In a broad sense, we can say: Radicalization is "a social and psychological process with an increasing commitment to an extreme political or religious ideology." Webster's dictionary defines the belief and support of ideas that are far removed from what most people in the world consider to be true and reasonable. People of all races, cultures and beliefs have used violence to advance their politics and personal interests. As mentioned; There is no universally agreed definition of the concept of "terrorism" and the term "violent extremism." According to Pressman and Flockton they can be considered as a continuum because people can without the use of force, contrary to the dominant culture to radical ideas aimed at political change, religious or community be convinced. However, it is also possible that people will see the use of force as an accepted legal means of achieving change, which refers to violent extremism. Sometimes they can be mutually used. However, there are several definitions that have been developed nationally, regionally and internationally. While terrorism and extremism are sometimes used intermittently, they are both a threat to students and other segments of society. Of course, relying on some sources, some clear definitions can be given for these two words: "Terrorism is an act or threat designed to influence the government or intimidate the people." "Its purpose is to advance a political, religious or ideological goal." But "oppose extremism actively and openly with fundamental values such as democracy, individual freedom, respect and tolerance of different faith and beliefs." It is important to note that not all extremist groups, whether Islamic, extremist right, etc., will commit acts of terrorism or violence. The line between radicalism and violent extremism can be very close. Although radical individuals do not participate physically in terrorist acts, they can play a prominent role in other areas, such as joining or opt to have people in the group. If, during this process, the individual is considered extremist. Based on their research, Sieckelinck et al., argue that radicalism can also be described in an educational sense because "when a child begins to develop political or religious ideas and powers, which are fundamentally different from the expectations of the educational environment 
or mainstream." That is why they consider education as a very important weapon in the fight against extremism. Although education is important in all stages of human life, many researchers in educational sciences believe that at the age of 7-15 years, the intensity of educational effects can be felt much higher than other periods of life. The training of terrorism and the creation of extremist religious circles are more likely to occur between the ages of 15 and 25; which is affected by emotional, mental and psychological deficiencies in the family or society or improper education during the period of 7 to 15 years, which engulfs different segments of society at an older age. As history shows, education can play an essential role in the behavior and beliefs of individuals and groups, and the educational environment can be considered one of the main places in spreading or curbing radicalization. In December 2015, the key role of education for the first time, the program "Action to prevent violent extremism," was approved by the UN SecretaryGeneral. The plan focuses on the main and most necessary preventive measures for people who have joined violent extremist groups. Quality education is considered one of the ways to deal with the drivers of radicalization. The UNESCO Executive Board has issued a resolution stressing the importance of education as a tool to prevent violent extremism and terrorism, as well as genocide, racial and religious intolerance, war crimes and crimes against humanity around the world. It is argued that education needs to be provided to improve social commitment processes and prevent violent extremism, whether through school systems, community centers and associations or at home. Many experts have proposed solutions to counter and control radicalization in developing countries. Because most terrorist attacks take place in them, for example, in six countries Afghanistan, Iraq, Nigeria, Syria, Pakistan and Somalia. These six countries accounted for $72 \%$ of the global terrorist attacks in 2015. Five new countries with more than 500 killed are; Ukraine, Yemen, the Central African Republic, South Sudan and Cameroon. Globally, the list of violent extremist attacks is growing. As everyone knows, violence can cause instability, which will hurt the results of the sustainable development of related countries. For example, due to the unrest in
Tunisia and Egypt, they saw a significant decline in tourism and foreign investment, which also reduced the growth rate of these countries.

It is clear that since the beginning of the $21 \mathrm{st}$ century, the death toll from violent extremism and terrorism has risen from 3,329 in 2000 to 32,685 in 2014, more than ninefold. However, OECD member countries saw an increase in terrorism-related deaths from 77 in 2014 to 577 in 2015. In the present study, an attempt has been made to present education in combating extremism in developing countries, especially Afghanistan. Because the roots of extremism are deeper than previously thought, and if not addressed through the weapon of education, the whole world will be gripped in the not-too-distant future. And while countless incidents of extremism and terrorism have caught the attention of the international community, most of the daily victims of violent extremism are ignored in Arab, African, Central European and Asian countries. Education seeks to educate civilized human beings with a sense of citizenship and universalism because the future of humanity is a future of peaceful coexistence.

\section{Education as a Tool to Combat Violent Extremism}

One of the greatest contemporary threats to the world is religious extremism, which has occurred around the world and can turn into deadly catastrophes. The spread of religious extremism around the world threatens not only one person or group. Rather, it poses a geographical threat beyond a single location and will take shape nationally and internationally. If we look closely, we will see that this phenomenon is growing and taking root. For example, since the start of the Syrian civil war in 2011, many people have been drawn to extremism, and they have gone to this country and extended the war in the name of jihad and struggle in the name of God. In the first half of 2013 alone, more than 600 foreign fighters were killed in Syria. By 2015, about 25,000 foreign fighters from 100 countries had joined ISIS. In 2013, 205 of India's 608 districts were affected by terrorist activities. According to the State Department, Terrorist attacks killed 231 civilians in India in 2012. It accounts for about 2\% of global terrorism casualties while accounting for $17.5 \%$ of the global population. The SATP lists 180 
terrorist groups that have been operating inside India for the past 20 years. Research on extremism shows that it mainly affects young men between the ages of 15 and 25. In countries such as Mauritania, Nigeria, Afghanistan, Syria, Yemen, Iraq, and several other countries, young people arrested for terrorism were between the ages of 16 and 24. Hutson et al., also found in their research that in the Middle East, men between the ages of 15 and 25 are more likely than any other population to engage in terrorism or political violence. It goes without saying that in much of the literature on Islamic extremism, radicalization is associated with adolescence.

According to Silber and Bhatt, the Process of Radicalization can be Identified in Four Stages

- People are not exposed to extremist beliefs and they have a relatively normal life.

- Self-knowledge refers to the introduction of individuals and their final acceptance of extremist ideas. Found in people between the ages of 15 and 35 , fundamental ideas and attitudes are formed.

- The extremist beliefs of individuals have intensified and they consider violence necessary to support these beliefs.

- The final steps towards violence are taken because the goals of the terrorist group or movement are completed before individuals.

Silber and Bhatt also noted in their studies that most radicalized people have a high school or university degree. The studies of these two people question the idea of terrorists being illiterate. Also, Sageman, based on a study of 172 Salafi-jihadi biographies, concluded that more than $60 \%$ of them had a degree. $88 \%$ of the leaders of these groups completed higher studies, of which $20 \%$ received doctorates. In their study, Krueger and Maleckova found that most terrorists in the Middle East received higher education. Osama bin Laden, the founder of the al-Qaeda network, an engineering graduate, and his successor, Iman al-Zawahiri, completed a master's degree in surgery. Abu Bakr al-Baghdadi, the leader of ISIS, had a doctorate in Islamic theology. Gambetta and Hertog, British sociologists, concluded in their research that 196 of the 284 people who were called international terrorists had higher education. The World Bank researched
ISIL recruitment and their average education. However, research and studies do not have the same conclusions. For example, Gill showed in his research that there is no evidence of the personal education of suicide bombers. Because a report prepared by the House of Commons after the July 2005 bombing in London does not directly link the characteristics of terrorists to higher education. According to Taspınar, mostly uneducated young people from the slums of Casablanca were recruited by an Islamic militant group into a Moroccan jihadist organization. In Sierra Leone and Nigeria, most extremist groups consisted of homeless, unemployed, single, and uneducated youth. Extremist groups intensively began providing education, housing, health, and employment services in high-poverty areas. For young people, membership in these radical groups provided new social opportunities with greater authority and responsibility, as well as opportunities for housing, employment, marriage, and religious education. In their research, Kiendrebeogo and Ianchovichina examined the characteristics of radicalized people in 27 developing countries. They concluded that the typical characteristics of a radicalized person are likely to be young, educated, and unemployed. Oyefusi, as a result of his research, found that insurgent groups in the Niger Delta were often a combination of large numbers of young people with less education and poorer socioeconomic status. In Rwanda, political elites were the main organizers of genocide because of their greater power. And were supported by the middle class, who feared losing points. During the 1994 Rwandan genocide, known as the darkest human tragedy of the last half-century, in addition to killing 800,000 men, women, and children, 200,000 to 500,000 women were raped. Afghanistan remains the most vulnerable country to extremist threats. Every year, many children, women and men in Afghanistan die as a result of attacks by extremist groups. In 2017 alone, 14,885 people died in Afghanistan, which has plagued this geography for 40 years. This year, air strikes were carried out in 29 of Afghanistan's 34 provinces, $55 \%$ of which took place in Helmand and Nangarhar. 21\% of Taliban documented violence has taken place in these provinces, and Helmand is Afghanistan's largest province, with opium reserves 
being a good source of funding for the Taliban. The GEM also recorded 590 Taliban-instigated incidents from the west of Farah province to Paktia in the east. In 2017, GEM recorded the deaths of 5,784 Taliban members due to the actions of the Afghan Army, US forces and the (NATO). ISIS extremists carry out their attacks differently from the Taliban. Although there are no deep sectarian divisions in Afghanistan such as Iraq and Syria, ISIL's 17 deliberate attacks on Afghanistan's Shiite population, which killed 238 civilians, have left ISIL determined to seize opportunities for religious strife. $26 \%$ of all ISIL activities in Afghanistan were sectarian and $60 \%$ of all attacks targeted civilians. The group was responsible for 11 attacks on Sunni and Shiite mosques in Afghanistan in 2017. The Taliban, meanwhile, have targeted the army and police in $79 \%$ of their attacks. According to the GEM, ISIL and the Taliban targeted NATO and the US military about 30 times in 2017, killing at least 15 US troops. ISIL killed 977 people in Afghanistan in 2018, with an average of at least 10 people killed in each attack. This made ISIL one of the deadliest groups in 2018. Conflicts and insecurities continue to affect the Afghan people of the extremist militancy in the country. In the violence related to Islamic extremism in 2018, at least 12,187 people lost their lives; we witnessed at least two attacks every day. Afghanistan has topped the list of deadliest countries since 2017 and is the second deadliest country globally, despite an 18\% drop in casualties in 2018 . \{In 2018, the number of people killed in Iraq will be less than in 2017. The fall of ISIS in Iraq and Syria reduced casualties by $79 \%$ in Iraq $\}$. ISIS has also emerged as a serious threat to the Taliban and the Afghan people. In 2018, clashes between the two organizations resulted in the deaths of 190 soldiers. $69 \%$ of this inter-group violence took place in Kunar and Nangarhar, where ISIL is concentrated. For example, an ISIL suicide bomber who targeted the funeral of a Taliban member killed 16 people in July 2018. While these groups are divided by ideological tactics and programs, overthrowing the government is a clear priority for both. At least 7,809 Islamist militants have been killed in joint efforts by Afghan security forces and their international partners, including the United States and NATO. In 2018,
President Trump approved plans to withdraw 7,000 troops from Afghanistan, the largest US withdrawal since the 2001 invasion - a military strategy that could prolong Islamist militancy in Afghanistan. The death of George Floyd, a black American, on May 25, 2020, by a Minneapolis police officer from the US state of Minnesota sparked a new wave of racial violence against blacks. The lack of proper and quality education, as well as the lack of jobs for young people, has forced many of them to cooperate with extremist groups such as the Taliban and ISIS. It has been about 40 years that radicalization and extremism have pervaded this geography and the people of this land have always suffered from it. On the other hand, the terrorists have frightened the small and large powers in the region. Everyone is worried that the extremists will regain power in Afghanistan and that this phenomenon will penetrate from Afghanistan to the borders of these countries. This could provide opportunities for Afghanistan on the difficult path to fighting terrorism.

\section{Activism of Extremist Groups in Educational Places}

The school informs people in age groups about the world of politics and the role they play in it. It also creates in children more objective perceptions of institutions and political relations. Schools also transmit values to society. They can play an important role in shaping one's statements about the unwritten rules of political play. Schools can be a source of interest in the political system and provide common symbols such as the flag and the oath of allegiance for a symbolic response to the system.

Terrorist organizations in many parts of the world are using training sites to recruit. Extremist groups are gaining members through schools, universities, prisons, and the Internet. In Afghanistan, ISIL uses various methods to attract children and adolescents, for example:

- Exploit children and adolescents from lowincome families and deceive their parents, and pay between $\$ 300$ and $\$ 500$ a month.

- Develop curricula to justify religious extremism, violence, and war, as well as specific lessons on fighting, murder, bombing, beheading, and suicide bombings. 
- We were putting them under intensive military training on special bases for direct combat and assassination.

- Show scenes of violence and encourage children to commit and participate in these criminal acts.

- They were showing videos and pictures of scenes of execution, beheading and crucifixion for children and adolescents.

- Re-interpretation of Quranic verses for children and adolescents and emphasis on jihad and the good news of Paradise.

- Publishing pamphlets and religious stories that endorse the extremist thinking and ideas of this group.

Numerous studies have shown that various networks in educational settings seek to attract people. For example, Latif stated in his research that Iraqi universities had become major centers for radicalization and recruitment of violent groups.

In Mauritania, the recruitment of radicalized youth is sometimes done in schools as well as in seminaries. In these educational systems, space is created for young people to interact with violent ideas and those who are far from these thoughts. This confrontation often leads to more acceptance of school graduates for violent extremist ideas. After the collapse of the Iraqi government in 2003, powerful student groups emerged on campus. Educational institutions, especially higher education, became ideological battlegrounds and fertile ground for extremist groups.

Over the past two decades, enrollment rates in educational institutions, especially schools, have increased in developing countries. In 2014 worldwide, $91 \%$ of children enrolled in primary education, while in countries with medium and low income, $81 \%$ and $90 \%$ of children participated, respectively. Worldwide, $84 \%$ of children enrolled in high school in 2014. In the middle- and low-income countries, $65 \%$ and $80 \%$ of children participated, respectively. $63 \%$ of children worldwide enrolled in secondary education, ranging from $40 \%$ in lowincome countries to $52 \%$ in low-middle-income countries. In 2016, 215.9 million young people enrolled in higher education, according to UNESCO. The lowest number is in Central Asia, where 2 million students participated. In sub-Saharan Africa,
7.4 million young people enrolled, while 26.2 and 10.8 million students pursued higher education in Latin America and the Arab world, respectively.

\section{Educational Problems in Geography Condemned to Extremism}

Since the purpose of education in all countries is to raise a generation interested in their national identity, is aware of individual and public laws, and is proud of being a veteran in the way of culture, originality and defense of the land. Know the skills of life and social etiquette, how to live and especially how to live together, and in the face of problems, do what they like for others, and accept human beings as members of each other. And always consider the law and its implementation as the principle.

As explained in the previous sections, there is no coherent view of the relationship between the level of education of young people and their radical beliefs or involvement in terrorist acts. However, econometric analyzes have shown that a link can be found between countries or regions with low levels of education and the risk of conflict.

\section{Based on these Analyzes}

- Lack of comprehensive education

- Lack of optimal quality in education

- Lack of job opportunities after graduation

It is often a source of tension, leading to radicalization, conflict, violence and insurgency.

\section{Lack of Comprehensive Education}

According to the research of scientists such as; (Moser \& Rodgers), there is a link between violence and unequal access to education, employment, health, or basic physical infrastructure. Conditions where widespread inequality is widespread increase the likelihood of hopeless and disadvantaged populations, which may increase the number of young people participating in various forms of violence. For example, Breidlid stated that deep-rooted grievances about unequal access to education systems in Sudan are among the reasons for the ongoing civil war in the country. Sudan was finally divided into North and South Sudan on July 9, 2011, after much conflict. In Sierra Leone, the government's failure to provide quality and equitable education distribution to young 
people led many to join rebel groups. It seems that unequal access to education is not limited to primary and secondary education, as discrimination is often hidden in university admissions. This was also the case for the Tamil youth in Sri Lanka, one of the main motivations for the youth to join the northern military movements during the 1970s. The Sri Lankan Civil War was one of the longest-running civil wars in modern history, beginning in 1972 and ending in May 2009 after the defeat of the Tamil Taliban. The United Nations says at least 100,000 people have been killed and hundreds of thousands injured or displaced in these wars. In their research, Shafiq and Sinno concluded that the relationship between a country's level of education and the risk of conflict is not direct. Political and socioeconomic variables may play a mediating role in this regard. This means that poor political and economic conditions may increase the likelihood of terrorist acts, while in favorable circumstances, education may further reduce terrorism.

Brockhoff et al., In their research of 133 countries over 23 years, concluded that lower levels of education, such as primary education, lead to more terrorism for a range of developing countries. Higher education, like university education, reduces domestic terrorism for a group of countries with more favorable conditions (economically, socially, politically, and culturally). Referring to the personalities of those who took part in the recent terrorist attacks, previous research has shown that equal access to education does not in itself minimize the risk of radicalization. Mercy Corps confirmed these findings after conducting a study to examine the impact of access to formal education on participation and support for Somali youth political violence. The results show that although improved access to secondary education reduces participation in political violence by $16 \%$, support for violence has increased by $11 \%$. However, when improving access to secondary education is accompanied by opportunities for civic participation, it allows young people to take practical action in the community, reducing by $14 \%$ and $20 \%$, respectively, participation and support for political violence. This means that a combination of educational initiatives with civic participation activities keeps young people away from violence. Therefore, providing education alone is not enough to prevent radicalization or the employment of young people.

In Afghanistan, too, young people and adolescents are drawn to extremist groups due to poor education. Bruce Hoffman, director of the Center for Security Studies at Georgetown University, sees Afghanistan as a possible new ISIL base after the group's defeat in Iraq and Syria. "The Islamic State in Iraq and Syria has focused a lot of attention and resources on Afghanistan," he said, referring to the "large stockpile of weapons" in the east. For example, on October 28,2020 , Tolo News reported the spread of nightly letters denouncing the Taliban and the people's concern about joining the group (ISIL). Meanwhile, the Taliban have embraced the peace process with the Afghan government, and negotiations for peace continue. Not to mention that Tolo News reported in a report quoted by the American Research Institute that from 2001 to 2019, only 157,000 Afghan citizens were killed as a result of the conflict.

\section{Lack of Good Quality in Education}

Brockhoff et al., Argued that equal access to education is effective only when combined with processes of radicalization with good quality education. The quality of good education depends on the training of good teachers. In some countries of the world, new policies have been designed to train teachers, which have led to favorable results and change the country from a state of poverty and backwardness to a developed country. The UN Security Council also emphasized the role of quality education in Resolutions 2178 and 2250. Policymakers in the education system in countries facing extremism must also adopt new methods for teacher training. Because giving importance to the modernization and revision of curricula and harmonizing the content and teaching methods with changing conditions is one of the important issues in the curriculum. Policymakers in the education system in countries facing extremism must also adopt new methods for teacher training. Because giving importance to the modernization and revision of curricula and harmonizing the content and teaching methods with changing conditions is one of the important issues in the curriculum. Teacher students 
should hold regular and intermittent meetings after graduation to have the opportunity to exchange experiences with each other. Because teachers are the starting point of any change in society, and they can also fight extremism and train students to have peaceful thoughts. Steer et al., found in their research that Arab countries have successfully invested in equal access to education, but the quality is low. Based on an analysis of 13 Arab countries, the researchers concluded that $48 \%$ of high school students did not pass the elementary numbers and literacy tests. Even students with higher scores still do not have the skills needed in the 21 st-century market. In their research, Ladbury and Hussein concluded that education in Pakistani schools and religious schools raises the expectations of young people. At the same time, a lack of skills prevents these expectations from being realized. Richards also argued that education systems in the Middle East, which are often based on preserving memories and requiring obedience to officials without asking any questions, make young students vulnerable to extremist narratives. From this perspective, Martin Rayo stated that the quality of education is a determining factor in the radicalization process of young people. Young people with little quality education reject violence and are less prone to ideological brainwashing by radical groups. During his research, Agbiboa found that poor education infrastructure and a shortage of teachers contributed to the fundamentalism of many young people in West Africa.

Education in extremist countries, such as Afghanistan, faces a shortage of teachers and a poor distribution of teachers. Inadequate distribution of professors can be seen not only in schools but also in universities. There are also problems with the quality of education, and part of the weakness of the quality of education has to do with how teachers are recruited, trained and retained. Most teachers have not received the necessary training for the teaching profession and have rarely revised and modified their knowledge, and teaching methods during inservice classes. Lack of motivation and attachment of teachers, expression of teachers' dissatisfaction directly and indirectly with living conditions due to low salaries and benefits of teachers, lack of motivation and desire in teachers in all levels of education from primary to higher education, Teachers do not feel that they have an independent job and professional identity, they promote a teacher not out of love and affection, but only to have a job.

It should be noted that the content of the curriculum greatly affects the quality of education. When communism and the Soviet Union were considered the greatest security threats to the West during the Cold War, the United States Agency for International Development (USAID) provided training programs in refugee camps in Pakistani schools. Between 1984 and 1994, more than 13 million textbooks were distributed among young people in Afghan refugee camps and schools in Pakistan. As these textbooks largely contained hated curricula for the Soviet Union, this led to a generation of radical and even extremist youth. In their research, Shafiq and Sinno concluded that the direct impact of education on radicalization and extremism depends on the content of the curriculum and the values that are considered in educational institutions.

Research has shown that in Rwanda, curricula and teaching methods neutralize critical thinking, affecting individuals' responses to genocide. In 2015, five schools in Uganda were closed because of allegations that they were teaching students to go to extremes in favor of a Congolese armed group attacking the African Union. According to Makalozo, the problem of radicalization and extremism is not solved by education alone but by the quality of education that can work. It is important for students to learn from other disciplines to be exposed to other perspectives, to have intelligent and critical discussions, and to understand international and domestic realities.

\section{Lack of Job Opportunities After Graduation}

As mentioned, many researchers emphasize the importance of high-quality education, but according to some, the relationship between education and the existing labor market is also very important. Bhatia, and Hilker, argue that a combination of quality education, but limited job opportunities, can create the ground for radicalization. The Counter-Terrorism Center announced in 2016 in a report that; Based on an analysis of 4,600 ISIL personnel from the Islamic State, most of them were relatively well educated 
compared to the level of education of their countries. Still, most of them did not have a suitable job or did not have a job.

Terrorist nests in Pakistan pose a major threat to its neighbors, especially Afghanistan. Afghanistan's strategic location and proximity to Central Asia and China and its good relations with India have made the phenomenon of extremism negatively impact the results of peace and sustainable development in Afghanistan. We can easily understand and observe the adverse effects of unemployment in Afghanistan. Bhatia and Ghanem, in their research, concluded that frustration with the impossibility of providing job opportunities commensurate with their level of education could play a role in the process of radicalization and extremism. In his research, Zaidi found that economic weakness forced highly educated and non-disabled people, who were often unemployed, to commit crimes to find simple solutions to the problem. And as a result, join large criminal and extremist groups.

If the level of education raises expectations in job opportunities and it is not possible to achieve it. This can create a "reality-expectation" relationship and increase the potential for extremist groups to operate. For example, ISIL always promotes job opportunities in its recruitment campaign. Research among Sri Lankan youth has shown that inadequate employment for educated people with high aspirations leads to intense competition, group membership and unrest. The Sinhalese People's Liberation Front and the Tamil Tigers recruited their cadres from the desperate rural youth with higher education. Today, in the Middle East and North Africa, a university degree has reduced it more than it has increased your chances of finding a job. An educated person does not seem to have any advantages in the labor market, even more disadvantages, because his expectations are not met. In addition, in Nigeria, due to frustration with the employment prospects, many young people have migrated from rural to semi-rural and even urban areas in search of a suitable job, which has increased radicalization processes. On the other hand, lack of jobs and a weak economy will cause chaos and riots, for example; Many unemployed youths took part in the 2004 Liberian uprising. DeJong also noted in his research that the regional uprising in Casamance in
Senegal was caused by youth and unemployment In an econometric study, Collier concluded that the biggest differences are in countries with low employment rates. According to his analysis, when a country increases the employment rate by $10 \%$, the risk of conflict can be reduced by $4 \%$. According to Brockhoff et al., it is clear that Countries are able and willing to provide opportunities and meet the expectations of their educated citizens achieve positive results. Because in countries or regions that cannot or do not want to meet the growing level of expectations, the pressure for forced change will increase. And that could have negative consequences for that country.

\section{Measures to Improve the Performance of Educators}

The current global security agenda emphasizes the importance of education in challenging radicalization and violent extremism and preventing youth participation in extremist groups. Board et al., argued that "there is no evidence that shows the best methods of education against extremism." While some studies show that equal access to education and national improvement limits academic achievement, radicalization, and participation in violent extremism, other researchers emphasize the importance of quality education and the availability of job opportunities. The World Bank 2011 Global Development Report showed that the consequences of growth and human costs are extreme violence and that violence has been a major constraint on sustainable development. The Frontlines report from the United Nationals Development Program emphasizes the key role of young people in preventing effective and long-term violent radicalization. It is argued that focusing on youth by protecting their rights, strengthening and resilience, and systematically integrating meaningful participation is used to promote sustainable development and peace. The socio-economic conditions of individuals play a role in attracting them to extremist groups, but there are other factors in each country, society and individuals for their dynamism. According to the $2006 \mathrm{UN}$ Global Counter-Terrorism Strategy, these dynamics include lack of good governance, marginalization in the social economy, political deprivation, unresolved 
long-term conflicts, lack of the rule of law, human rights violations, ethnic, racial discrimination, national and religious.

Based on the findings and citing research by scientists, some recommendations can be made for the education sector in developing countries:

- Policymakers must provide sufficient resources to improve equal access to education. Research has shown that lack of equal access to education for young people puts them at greater risk of radicalization, employment in violent groups, or participation in criminal incidents.

- Education should be available to all, especially to the most marginalized and remote areas.

- Educational initiatives provide opportunities to raise awareness of extremist group recruitment strategies and encourage students to think about their plans. This means that education must be more attractive than other options such as conflict and violence.

- It must be said that education alone cannot resist extremism, but quality education can be a good answer to counter extremism. Based on her research, Rose concluded that "education itself is not responsible; rather, the right kind of education can be responsible." Many researchers emphasize the importance of school as a safe space for young people to explore their ideas freely. Thus, Pratchett et al., argued in their research that education could be effective in challenging ideology while focusing on individuals' ability to develop independent thinking and create a space for questioning and challenging themselves and others. Osler also argued that in this safe learning environment, one should talk about sensitive political issues and ideals without harming any individual or group. Davies described it this way: "In safe spaces, turbulence must be created to see how it can be remedied - and even requires different types of turbulence." According to Makalozo, critical thinking can act as resistance to the pulling factors of radicalization. Therefore, schools should be an environment in which critical thinking is nurtured, and students are encouraged to ask questions and learn to think beyond common taboos and assumptions. In this way, they can transfer their critical thinking skills to other situations outside the educational environment.

- According to recent research, the focus of developing countries is more on education. In Afghanistan, for example, more attention is paid to higher education, Of course, there is not much cost for the higher education system. However, more attention is paid to higher education than in elementary school and in several other countries, more attention is paid to secondary schools. While in the educational system reform strategies, it is necessary to pay attention to primary, secondary and higher education. One of the goals of developing the third millennium, ensuring the completion of all primary schools for children, is considered a key step in reducing poverty and achieving sustainability. Linking this issue to radicalization, Mercer argued that universal access to primary education was important for flexibility among young students. Improving personal flexibility should lead to better coping strategies for life's pressures and challenges and critical thinking skills to appreciate different perspectives. Barakat and Milton argued that higher education institutions could be effective for young men and women in maintaining hope and continuing to live for progress and liberation from violent groups. According to Ozerdem and Jacoby, higher education can play a key role in dismantling armed groups and creating weapons collection programs. For example: Research has shown that while large numbers of university students fought in Libya during the war, the reopening of universities in the post-war period is a positive contribution to stability in the country. Opening Universities to critical thinking can be effective in preventing students from becoming radicalized and extremist.

- Research has shown that people with higher education support violent extremism in the event of unemployment or underemployment. Changes in the education sector must be accompanied by reforms in the labor market. This means that the interaction between unemployment and higher education needs more attention. Policymakers should pay attention not only to the training and supply of labor but also to the demand for labor. 
Labor markets must be reformed to deal with the phenomenon of unemployed but educated youth. Because education and skills play a key role in securing employment, this can break the cycle in which joining an extremist group is considered the only viable option.

\section{Conclusion}

As we know, extremism has created different views among humanity, and different religions, denominations and sects are attacking each other to present themselves as superior and right in any way. In this way, they do not hesitate to do anything. It is a fact that the victims of terrorism are more than the developing countries because most of the terrorist attacks have taken place in them. Because one of the greatest contemporary threats to global security is the global phenomenon of religious extremism, which has occurred around the world and can turn into deadly catastrophes, The spread of religious extremism around the world will not only threaten an individual and a group but also a geographical threat beyond a place, and will take shape nationally and internationally. If we look closely, we will see that this phenomenon is growing and taking root. For example, \{since the start of the Syrian civil war in 2011, many have been drawn to extremism, and they have gone to this country and increased the duration of this war in the name of jihad and struggle for the sake of God. In the first half of 2013 alone, more than 600 foreign fighters were killed in Syria. By 2015, about 25,000 foreign fighters from 100 countries had joined ISIS.\} This article aims to examine the role of education in countering the extremism of young people in developing countries with an emphasis on Afghanistan. It also became clear that radical movements not only attract unemployed and uneducated young people but also those with higher education. The school environment often acts as recruiting sites in these processes. Based on these findings, the education sector is considered a prominent partner in preventing radicalization and violent extremism. Because new jihadist sects with different ideologies continue to advance through the system of schools, colleges and universities, the fight against this phenomenon has taken extensive and costly measures; \{ By 2015, the cost of fighting extremism was estimated at approximately \$ 5 trillion, and since 2016, the fight against ISIS has cost $\$ 11$ million a day.\} As you know, these costs have not yet been able to curb extremism. If half of this cost is spent on education for two consecutive decades and the necessary awareness to deal with extremism and its consequences are given to the students and their families through the indigenous people (teachers of each region). And the government should enact laws so that contradictory fatwas are not issued in the name of religion. And the actions and speeches of clerics and mullahs in religious schools to be controlled by a pacifist government body. And that no child is left out of school, we will see this phenomenon eradicated. Because all the people who join extremist groups are somehow far from educated or inappropriate and extremist education has led them to extremism. As mentioned in the article, the three potential limitations of the education sector examined are lack of inclusive education, lack of quality in education, and lack of job opportunities after graduation, which can increase the vulnerability of young people to radicalization and extremism. Recourse to psychology and empathy, support, admiration, and finally, brainwashing make them a tool to implement their goals in religion. If the saviors of education take the necessary measures to prevent this misconduct and try to find the root of the problem in any environment and with insight and wise measures, and for students to practice fraternity, equality, and peacefulness (Pluralism) in the classroom, we will see that this problem will be eliminated. The government of the men of Afghanistan must understand that the situation in Afghanistan is very different from that of its neighbors. Because in recent decades, Afghanistan was the only country that suffered the most human and financial losses from extremism and terrorism. Millions of its citizens were killed, displaced and homeless, and the most valuable assets and cultural and civilizational heritage of this land were destroyed or looted. The presence of terrorist and extremist groups in Afghanistan has pushed the level of knowledge, expertise and literacy in the country to its lowest possible level due to the closing of the gates of schools and universities. In short, proper education has the potential and power to deal with 
this phenomenon. Because teaching enables learners to move independently toward their goals and find a special identity in society, it is of undeniable importance in the course of our lives.

\section{List of Acronyms}

GEM: Global Extremism Monitor

NATO: $\quad$ North Atlantic Treaty Organization

OECD: Organisation for Economic Co-operation and Development

SATP: $\quad$ South Asian Terrorism Portal

UNESCO: United Nations Educational, Scientific and Cultural Organization

UN: $\quad$ United Nations

USAID: United States Agency for International Development

ISIL = ISIS: Islamic State of Iraq and Syria, also known as ISIL (Islamic State of Iraq and the Levant)

\section{References}

“Afghanistan's Taliban, US sign peace deal." AlJazeera, 2020.

Abbasi, Manzoor Ahmed. "Towards the Deradicalization of Pakistani Society: The Need for a Balanced and Progressive Education System." Dialogue, vol. 9, 2014, pp. 255-270.

Agbiboa, Daniel E. "The Nigerian Burden: Religious Identity, Conflict and the Current Terrorism of Boko Haram." Conflict, Security \& Development, vol. 13, no. 1, 2013, pp. 1-29.

Ainscow, Mel, and Susie Miles. "Making Education for All Inclusive: Where Next?" Prospects, vol. 38, 2008, pp. 15-34.

Barnes, J. Why is Terrorism so Hard to Define. National Security Zone. 2012.

Bhatia, Kartika, and Hafez Ghanem. "How do Education and Unemployment Affect Support for Violent Extremism?" Brookings, 2017.

Bird, L. Post-Conflict Education: A Review of Literature and CfBT Experience. The Centre for British Teachers, 2003.

Bloom, Mia. "Constructing Expertise: Terrorist Recruitment and "Talent Spotting" in the PIRA, Al Qaeda, and ISIS." Studies in Conflict Terrorism, vol. 40, 2017, pp. 603-623.
Bonnell, Joe, et al. Teaching Approaches that Help to Build Resilience to Extremism among Young People. Department for Education, 2011.

Botha, Anneli, and Mahdi Abdile. Radicalisation and al-Shabaab Recruitment in Somalia. Institute for Security Studies, 2014.

Boukhars, Anouar. "The Drivers of Insecurity in Mauritania." Carnegie Endowment for International Peace, 2012.

Braniff, B. Understanding Terrorism and the Terrorist Threat. National Consortium for the Study of Terrorism and Responses to Terrorism (START), 2015.

Breidlid, Anders. "Sudanese Migrants in the Khartoum Area: Fighting for Educational Space." International Journal of Educational Development, vol. 25, 2005, pp. 253-268.

Brockhoff, Sarah, et al. Great Expectations and Hard Times: The (Nontrivial) Impact of Education on Domestic Terrorism. CESifo Working Paper no. 3817, 2012.

Brockhoff, Sarah, et al. Ties That Do Not Bind (Directly): The Education Terrorism Nexus Revisited. CIE Working Paper Series, 2010.

Brockhoff, Sarah, et al. "Great Expectations and Hard Times: The (Nontrivial) Impact of Education on Domestic Terrorism." Journal of Conflict Resolution, vol. 59, no. 7, 2015.

Burde, Dana, et al. What Works to Promote Children's Educational Access, Quality of Learning, and Wellbeing in Crisis-Affected Contexts. Education Rigorous Literature Review, 2015.

Collier, Paul. "African Growth: Why a 'Big Push'?" Journal of African Economies, vol. 15, 2006, pp. 188-211.

"Critical Choices: Assessing the Effects of Education and Civic Engagement on Somali Youth's Propensity towards Violence." Mercy Corps, 2016.

Davies, Lynn. Review of Educational Initiatives in Counter-Extremism Internationally: What Works? The Segerstedt Institute Report, 2018.

Davies, Lynn. Unsafe Gods: Security, Secularism and Schooling. Trentham Books, 2014.

Davies, Lynn. "Educating Against Extremism: Towards a Critical Politicization of Youth 
People." International Review of Education, vol. 55, 2009, pp. 183-203.

Davies, Lynn. "Learning for State-Building: Capacity Development, Education and Fragility." Comparative Education, vol. 47, no. 2011, pp. 157-180.

Davies, Lynn. "Security, Extremism and Education: Safeguarding or Surveillance?" British Journal of Educational Studies, vol. 64, no. 1, 2016, pp. 1-19.

Dearden, Lizzie. "Isis Advertises 10 Jobs in the 'Caliphate' including Press Officers, Bomb Makers and Teachers." The Independent, 2015.

Decisions Adopted by the Executive Board at Its 197th Session. UNESCO, 2015.

De Jong, F. The Casamance Conflict in Senegal. Report for the Project the Causes of Conflict in the Third World. Netherlands Institute for International Relations, 1988.

de Silva, Samantha. The Role of Education in Combating Violent Extremism, 2015.

Dollar, David and Lant Pritchett. Assessing Aid: What Works, What Doesn't, and Why. World Bank, 1998.

Education for People and Planet: Creating Sustainable Futures for All. UNESCO, 2016.

Fink, Naureen Chowdhury, and Rafia Bhulai. "Development and Countering Violent Extremism." SDGs: The People's Agenda, 2016.

Gambetta, Diego, and Steffen Hertog. "Why are there so many Engineers among Islamic Radicals?" European Journal of Sociology, vol. 50, no. 2, 2009, pp. 201-230.

Gill, Paul. "A Multi-Dimensional Approach to Suicide Bombing." International Journal of Conflict and Violence, vol. 1, 2007.

Global Extremism Monitor: Violent Islamist Extremism in 2017. Tony Blair Institute for Global Change, 2018.

Global Terrorism Index 2018: Measuring the Impact of Terrorism. Institute for Economics and Peace, 2018.

Hilker, Lyndsay M., and Erika Fraser. Youth Exclusion, Violence, Conflict and Fragile States. Social Development Direct, 2009.
Horgan, John. Walking Away from Terrorism: Accounts of Disengagement from Radical and Extremist Movements. Routledge, 2009.

"How George Floyd was Killed in Police Custody." The NewYork Times, 2020.

Human Development Report 2019. United Nations, 2019.

Hutson, Royce, et al. "Pathways to Violent Radicalisation in the Middle East: A Model for Future Studies of Transnational Jihad." The RUSI Journal, vol. 154, no. 2, 2009.

Institute for Statistics. Data for the Sustainable Development Goals. http://uis.unesco.org

Ismail, Olawale. "Radicalisation and Violent Extremism in West Africa: Implications for African and International Security." Conflict, Security and Development, vol. 13, 2013, pp. 209-230.

Jones, Edgar. "The Reception of Broadcast Terrorism: Recruitment and Radicalisation." International Review of Psychiatry, vol. 29, 2017, pp. 320-326.

Khan, Syed Abdul Rehman, and Zhang Yu. "Terrorism in Emerging Economies: A Double-Edged Sword." Terrorism and Developing Countries. Intech Open, 2019.

Kiendrebeogo, Youssouf, and Elena Ianchovichina. Who Supports Violent Extremism in Developing Countries? Analysis of Attitudes Based on Value Surveys. The World Bank, 2016.

Krieger, Zvika. "Iraq's Universities Near Collapse." The Chronicle Higher Education, 2007.

Krueger, Alan B., and Jitka Maleckova. Education, Poverty, Political Violence and Terrorism: Is There a Causal Connection?; National Bureau of Economic Research, 2002.

Ladbury, S., and M. Hussein. Developing the Evidence Base for Hypotheses on Extremism and Radicalisation in Pakistan. Independent Report to DFID, 2008.

Latif, A. Democratization and Radicalization in Iraqi Campuses. Iraqi Prospect Organisation, 2006.

Mamdani, Mahmood. When Victims Become Killers: Colonialism, Nativism, and the Genocide in Rwanda. Princeton University Press, 2002. 
Martin-Rayo, Francisco. Countering Radicalization in Refugee Camps: How Education can Help Defeat AQAP; The Dubai Initiative, Belfer Center for Science and International Affairs, Harvard Kennedy School, 2011.

Mercer, Malcolm. Universal Access to Education in Gaza. DFID Human Development Resource Center, 2011.

Milton, Sansom, and Sultan Barakat. "Houses of Wisdom Matter: The Responsibility to Protect and Rebuild Higher Education in the Arab World." Brookings, 2015.

Milton, Sansom. The Neglected Pillar of Recovery: A Study of Higher Education in Post-War Iraq and Libya. University of York, 2013.

Mohammadi, Mohammad. A Comparative Study of the Role of Education in Violent Extremism in Afghanistan and India. 2020.

Mohammadi, Mohammad. "Problems of Education in Afghanistan." Subhekabul, 2020.

Mohammadi, Mohammad. "The Role of Education in Combating Violent Extremism in Afghanistan." 8 a.m. Newspaper, 2020.

Moser, Caroline, and Dennis Rodgers. Change, Violence and Insecurity in Non-Conflict Situations; Overseas Development Institute, 2005.

Munasinghe, Sandun, et al. "Global Extremism Monitor: Islamist Violence after ISIS." Tony Blair Institute for Global Change, 2020.

Novelli, Mario. "Education and Countering Violent Extremism: Western Logics from South to North?" Compare: A Journal of Comparative and International Education, vol. 47, 2017, pp. 835-851.

Onuoha, Freedom C. The Islamist Challenge: Nigeria's Boko Haram Crisis Explained." African Security Review, vol. 19, no. 2, 2010, pp. 54-67.

Osler, Audrey. "Patriotism, Multiculturalism and Belonging: Political Discourse and the Teaching of History." Educational Review, vol. 61, 2009, pp. 85-100.

Oyefusi, Aderoju. "Oil and the Probability of Rebel Participation among Youths in the Niger Delta of Nigeria." Journal of Peace Research, vol. 45, no. 4, 2008, pp. 539-555.
Ozerdem, Alpaslan, and Tim Jacoby. Post-War Recovery: Disarmament, Demobilization and Reintegration. Bloomsbury, 2009.

Peris, V. "Two Decades after the Burning Down of the Jaffna Library in Sri Lanka." World Socialist Web Site, 2001.

Peters, Krij, and Paul Richards. "Why We Fight': Voices of Youth Combatants in Sierra Leone." Africa, vol. 68, 1998, pp. 183-210.

Plan of Action to Prevent Violent Extremism. United Nations, 2015.

Pratchett, Lawrence, et al. Preventing Support for Violent Extremism through Community Interventions: A Review of the EvidenceRapid Evidence Assessment Full Final Report. Department for Communities and Local Government, 2009.

Pressman, D. Elaine, and John Flockton. "Calibrating Risk for Violent Political Extremists and Terrorists: The VERA 2 Structured Assessment." The British Journal of Forensic Practice, vol. 14, no. 4, 2012, pp. 237-251.

Preventing Terrorism and Countering Violent Extremism and Radicalization that Lead to Terrorism. Organization for Security and Cooperation in Europe, 2014.

Quoting a Research Institute in the United States. TOLO News reports, 2020.

Report of the Official Account of the Bombings in London on 7th July 2005. The Stationery office, London, 2006.

Resolution 2178: Threats to International Peace and Security Caused by Terrorist Acts. United Nations, 2014

Resolution 2250. United Nations, 2015.

Richards, A. Socio-Economic Roots of Radicalism? Towards Explaining the Appeal of Islamic Radicals. DIANE Publishing, 2003.

Richards, Paul. The Political Economy of Internal Conflict in Sierra Leone. Clingendael Institute, 2003.

Roots of Violent Radicalisation. Home Affairs Committee, 2012.

Rose, M. Universities and 'radicalisation' in the Middle East and North Africa. 2017.

Sageman, Marc. Understanding Terror Networks. University of Pennsylvania Press, 2004. 
Sas, Marlies, et al. "The Role of Education in the Prevention of Radicalization and Violent Extremism in Developing Countries." Sustainability, 2020.

Schmidle, Nicholas. "The Saharan Conundrum." The New York Times Magazine, 2009.

Schönteich, M. The Dangers of Youth? Linking Offenders, Victims and Age. 1999.

Shafiq, M. Najeeb, and Abdulkader H. Sinno. "Education, Income, and Support for Suicide Bombings: Evidence from Six Muslim Countries." Journal of Conflict Resolution, vol. 54, no. 1, 2010, pp. 146-178.

Sieckelinck, Stijn, et al. "Neither Villains nor Victims: Towards an Educational Perspective on Radicalisation." British Journal of Educational Studies, vol. 63, no. 3, 2015, pp. 329-343.

Silber, Mitchell D. Radicalization in the West: The Homegrown Threat. Police Department, New York, 2007.

Snow, David A., et al. "Social Networks and Social Movements: A Microstructural Approach to Differential Recruitment." American Sociological Review, vol. 45, no. 5, 1980, pp. 787-801.

Sommers, Marc. "Embracing the Margins: Working with Youth amid War and Insecurity." Too Poor for Peace?: Global Poverty, Conflict and Security in the 21st Century. Edited by Lael Brainard and Derek Chollet, Brookings Institution Press, 2007, pp. 101-118.

Steer, Liesbet, et al. Arab Youth: Missing Educational Foundations for a Productive Life? The Center for Education at the Brookings Institution, 2014.
Talbot, Christopher. Education in Conflict Emergencies in Light of the Post-2015 MDGs and EFA Agendas. NORRAG, 2013.

Taspınar, Ömer. "Fighting Radicalism, not "Terrorism": Root Causes of an International Actor Redefined." SAIS Review of International Affairs, vol. 29, no. 2, 2009.

The Role of Education and Youth in Preventing Urban Violence and Countering Violent Extremism. INEE, 2015.

"Uganda shuts down 5 Madrassas over Training Extremists." Daily Mail, 2015.

UN Global Counter-Terrorism Strategy. United Nations, 2006.

Veldhuis, Tinka, and Jorgen Staun. Islamist Radicalisation: A Root Cause Model. Netherlands Institute of International Relations, 2009.

Wintrobe, Ronald. Rational Extremism: The Political Economy of Radicalism. Cambridge University Press, 2009.

World Development Report. World Bank, 2011.

Zaidi, Syed Abbas. "The Poverty-radicalisation Nexus in Pakistan." Global Crime, vol. 11, no. 4, 2010, pp. 399-420.

Zenn, Jacob. Increasing Numbers of Central Asian Jihadists in Syria. Central Asia Caucasus Institute, 2013.

https://educateagainsthate.com/what-is-extremism https://en.wikipedia.org/wiki/Rwandan_genocide https://en.wikipedia.org/wiki/Sri_Lankan_Civil_ War

https://en.wikipedia.org/wiki/Sudan https://en.wikipedia.org/wiki/ Terrorism in_India https://www.hawzahnews.com/news/906516

https://www.theguardian.com/world/2020/ feb/29/us-taliban-sign-peace-agreementafghanistan-war

\section{Author Details}

Mohammad Mohammadi, Contract Lecturer, Herat University, Herat, Afghanistan,

Email ID: fardin.m400@gmail.com 